\title{
OPERATIVNÍ PLÁNOVÁNÍ, VEDENÍ A KONTROLA - EKONOMICKÝ DENÍK
}

\section{OPERATIONAL PLANNING, MANAGEMENT AND CONTROL - ECONOMIC DIARY}

\author{
Vinh Phu Vu \\ CZ/VNM, Drnovská 20/45, Praha 6, 161 00, Czech Republic, vuphu.vinh@vpvcon.com, \\ $(+420) 720299490$
}

\begin{abstract}
Abstrakt - CZ
Tato práce se zabývá problematikou operativních plánů na stavbách a jejich kontroly. Práce obsahuje teoretickou a praktickou část. $V$ teoretické části autor zdůvodňuje, proč je operativní plánování na stavbě důležité a popisuje způsoby, jak se dají operativní plány vést. Dále analyzuje a popisuje chyby, které se při operativním plánováním vyskytují a jakým způsobem se dají omezit. Další část je zaměřena na popis softwarů, které fungují jako zpětná kontrola $k$ operativním plánům a dokáží sledovat náklady $v$ reálném čase. $V$ této části práce se autor bude zabývat hlavně svým softwarem, který je používaný již v několika českých firmách.
\end{abstract}

Klíčová slova - CZ

Operativní plánování, kontrola nákladů, software pro kontrolu nákladů v reálném čase, rozpočty, časový skluz informací.

\section{Abstract - EN}

The topic of this paper is about operational planning of construction site and their control. This paper has two parts. The first part is theoretic and the second part is practical. In the theoretical part of this paper the writer describing how to do operational planning and explains its importance. Further, the paper will introduce the reader with the type of operational planning, their strengths and weaknesses. The next part of this paper is practical and is focused on software, which is used for controlling the cost of a construction site in real time. This part contains an instruction on how to control operational plans.

\section{Keywords - EN}

Operational planning, cost control, software for controlling cost on site construction in real time, budget, time information delay

\section{JEL Classification}

O31 Innovation and Invention: Processes and Incentives

DOI: https://doi.org/10.14311/bit.2016.01.05

Editorial information: journal Business \& IT, ISSN 2570-7434, CreativeCommons license (c) (1) published by CTU in Prague, 2016, http://bit.fsv.cvut.cz/ 


\section{Úvod}

Plánování a plány jsou základním pilířem úspěchu v každém projektu. Čím více je plán přesný a srozumitelný, tím pravděpodobnější bude úspěšné dokončení projektu. Jedná se o klíčovou funkci managementu, a proto se týká všech oborů a aspektů organizace.

Plánování je proces, jehož výsledkem je plán. Jedná se o podrobný popis cesty, jak nejefektivněji dojít k cíli.

Plánování můžeme rozdělit podle několika hledisek na:

Časové hledisko

Dlouhodobé (delší než 5 let)

Střednědobé (1-5 let)

Krátkodobé (kratší než 1 rok)

Úrovně rozhodování

Strategické (rozhodnutí na vrcholové úrovni, dlouhodobé plány jako jsou třeba vize)

Taktické (rozhodnutí na úrovni středního managementu, střednědobé plány, jaké jsou třeba harmonogramy stavby)

Operativní (rozhodnutí na úrovni manažera 1. linie - stavbyvedoucí. Jedná se o krátkodobé plány)

Frekvence zpracování

Jedinečné (vize, mise, harmonogram $k$ jedinečné stavbě)

Rutinní (taktické, operativní plány, které jsou sestavovány průběžně)

Ve své práci bych se rád zaměřil na operativní plány a operativní plánování, tedy hlavní povinnosti manažera 1. linie. Operativní plány musí být ze všech typů plánu ve stavebnictví ty nejpřesnější a nejdetailnější. Společně s výkresovou dokumentaci totiž tvoří základ pro organizaci výstavby projektu. Operativní plány jsou nezbytné při složitých výstavbách, kdy je nutné práci organizovat s týdenním nebo i měsíčním předstihem (převedení dopravy při rekonstrukcích mostů, plánování výluk u metra atp.). Při typových výstavbách (rodinné domy, rekonstrukce bytových jader, zateplování fasád) firmy operativní plánování př́liš nepoužívají. Důvodem je ztráta času při jejich vytváření a malý užitek, když „vědí co dělají a dělají to celý život". Toto je však největší omyl, za který mnoho firem v krizi ve stavebnictví (rok 2008-2015) zaplatilo svoji existenci. Správně zpracovaný operativní plán totiž nejenom že urychlí a zpřesní výstavbu, $v$ budoucnu však také dokáže posloužit jako přesná databáze cen pro budoucí naceňování zakázek.

Operativní plánování Ize rozdělit podle charakteru na:

Operativní plán činností

Časový operativní plán

Ekonomický operativní plán

Nejčastěji se na stavbách používají operativní plány činností, kdy stavbyvedoucí napíše mistrovi činnosti, které se za den/ týden musí na stavbě stihnout. Jedná se o nejjednodušší plánování, kdy stačí tužka a papír či jednoduchý textový nebo tabulkový editor. Tyto činnosti jsou plánovány v závislosti na harmonogramu stavby.

Časově operativní plán je již nadstavba operativního plánu činností. Takový plán se většinou vytváŕí $v$ horizontu týdne/měsíce. Zde se kromě údaje činnosti také objevuje parametr času. Nestačí již naplánovat co se bude dělat, ale také kdy. Takovýto operativní plán se velice často objevuje na velkých stavbách s mnoha stavebními objekty, které na sebe navazují. V praxi se jedná o podrobný Gantův diagram, který je plánován na týden. 
Ekonomický operativní plány se na stavbách v České Republice př́liš nevedou. Mnoho firem v předvýrobní prípravě vytváří takzvaný finanční harmonogram, který však v průběhu stavby, pokud se neaktualizuje, ztrácí smysl. Správně vedený ekonomický operativní plán vám nejenomže ukáže, zdali vaše činnosti na stavbě probíhají podle harmonogramu, ale také jak se pohybují vaše náklady $v$ reálném čase. Tento typ plánu $v$ sobě propojuje jak činnosti, tak čas a náklady.

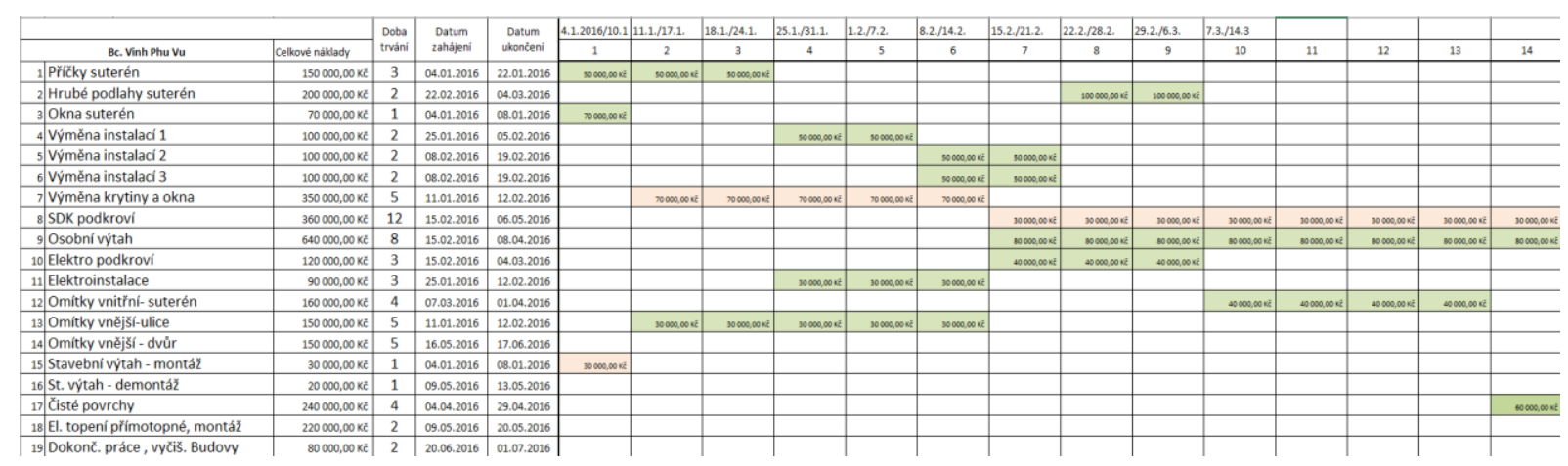

Obr. 1 Finanční harmonogram

Problémem, který ve své práci budu řešit je, jak zefektivnit operativní plánování na stavbách a zlepšit sledování prímých nákladů.

Na většině staveb se setkáme s nějakým druhem operativního plánování, at' už jde o nejjednodušší formu pomocí operativního plánu činností nebo složitějším časovým operativním plánování. Tyto plány pomáhají stavbyvedoucím a mistrům zorientovat se $v$ harmonogramu prací a lépe si naplánovat činnosti, které vedou ke splnění určitého úkolu v celkovém harmonogramu stavby.

Co se však na stavbách př́liš nepoužívá jsou ekonomické operativní plány. Největším důvodem, proč se na stavbách v České Republice př́liš nepoužívá je neznalost jeho vytvoření a časová náročnost. Přitom kdyby se použil správný software, nebo způsob vedení, tak vytvoření plánu a jeho vedení netrvá déle než pět minut denně.

Při správné tvorbě a vedení ekonomického operativního plánu získáme lepší přehled nejen o stavbě jak v čase a činnostech, ale také o ekonomice, ve které na stavbách bývá veliký problém. 


\section{Používáte na stavbách ekonomický operativní plány?}

a) Ano 3

b) $\mathrm{Ne} \quad 17$

Používáte na stavbách ekonomický operativní plány?

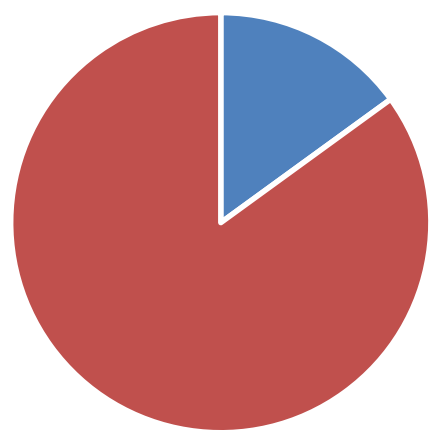

- a) Ano b) $\mathrm{Ne}$

Pokud ne tak proč?

a) Časově náročný 10

b) Není potřeba tyto plány dělat 3

c) Nevím, co to je a jak se plán dělá

Pokud ne tak proč?

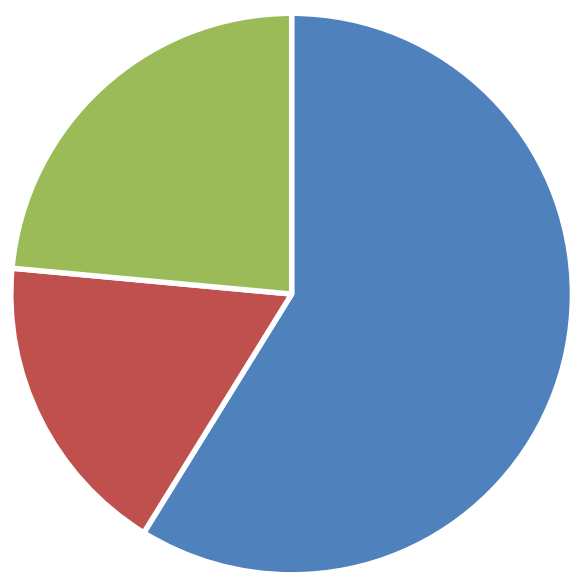

- a) Časově náročný a vení potřeba tyto plány dělat

- c) Nevím co to je a jak se plán dělá 
Nejenom uhlídat ekonomicky stavbu, ale mít i denní přehled začíná být ve stavebnictví čím dál tím těšší. $V$ době, kdy musí manažeři fungovat jako ekonomové, a přitom mají tři až čtyři stavby je téměř nemožné mít detailní přehled o každé stavbě. Stejný případ se děje i ve větších firmách kde mají ekonoma, ale ten zas má mnohdy tř̌i a někdy i více staveb roztroušených v několika krajích.

Proto hlídání ekonomiky na stavbách často sklouzává ke kontrole podle účetnictví. Náklady se kontrolují podle odešlých objednávek a přijatých faktur. Vzniká zde problém, že zatímco náklad na činnost vzniká reálně po dokončení a převzetí produktu, faktura je poslána až dokončení prací na konci měsíce. Díky tomu, že faktury mají dobu splatnosti většinou třicet dní, se náklad v účetnictví objeví někdy až po třech měsících poté, co byla činnost dokončena. Pokud tedy činnost nákladově stojí více než kolik by měla podle výrobní kalkulace, se proto většinou dozvídáme až po jejím dokončení. Dochází k takzvanému časovému skluzu informací.

Na stavbyvedoucích tak zůstává, aby ekonomii prímých nákladů dokázali na stavbě uhlídat sami a uměli si nastavit plán a kontrolovat její plnění a nespoléhat se pouze na informace od svého ekonoma. Jakmile totiž ekonom řekne, že položka nevyšla podle kalkulace, už je př́liš pozdě.

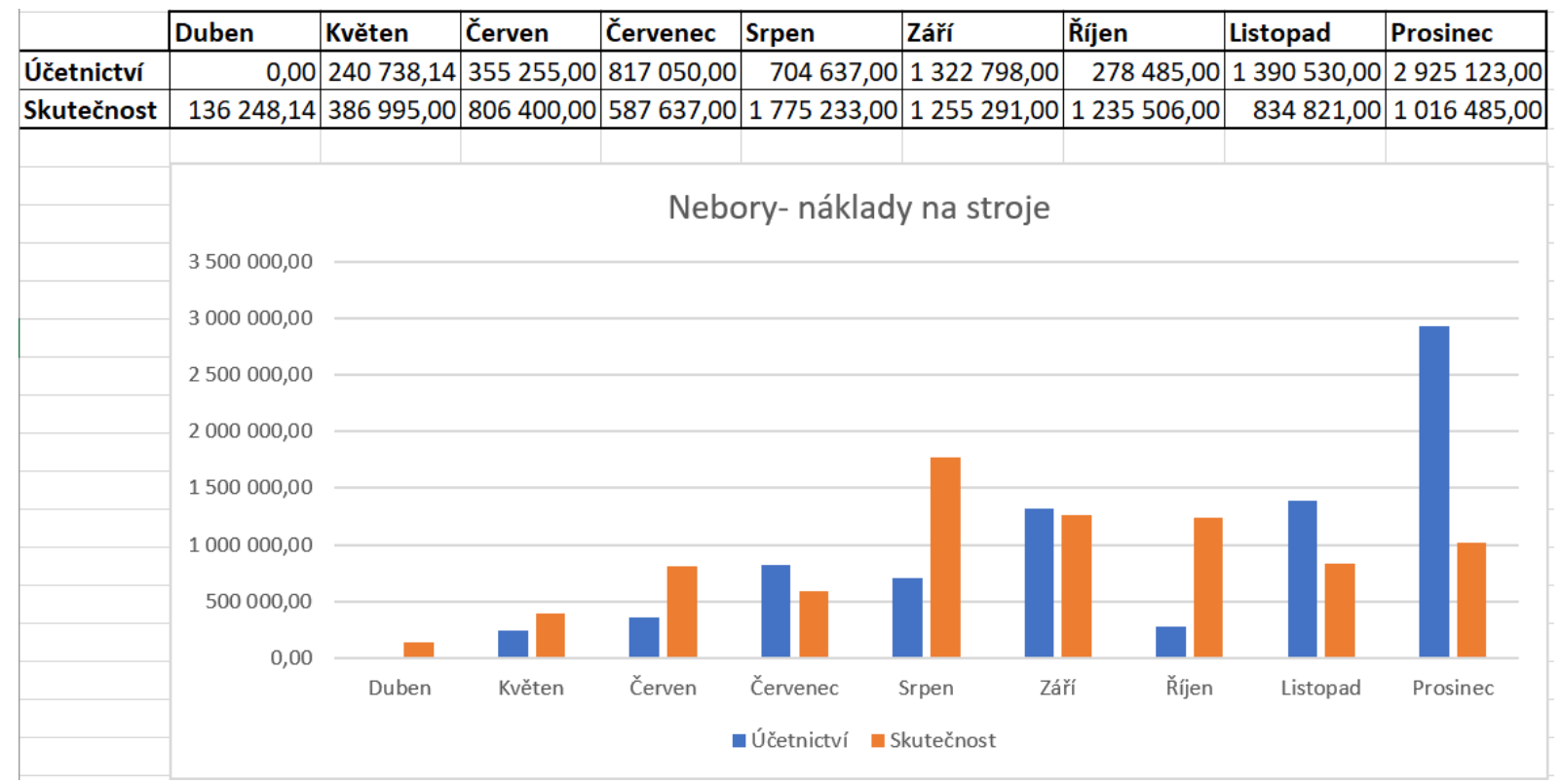

Obr. 2 Účetnictví vs. skutečnost

Toto je graf z reálné stavby, kdy byla ekonomie na stavbě sledována pomocí účetnictví. Jak napríklad vidíme, $v$ dubnu za mechanizaci do účetnictví nespadlo nic, ale reálně tam stroje byli za 136 tisíc. Takto to šlo každý měsíc, účetnictví nereflektovalo skutečnost a téměř pokaždé byla částka menší. Až v prosinci došlo ke zlomu, kdy většina firem uzavírala účetnictví a opravila či poslala fakturu za provedené práce. $V$ prosinci proto náklady na mechanizaci napadali do účetnictví $v$ částce téměř 3 milionů. Nikdo s touto částkou samozřejmě nepočítal, ale už bylo pozdě cokoliv řešit.

Celou dobu se tušilo, že mechanizace bude stát více, protože investor, který měl udržovat cesty, svoji povinnost nedělal. Kvůli dobrým vztahům s investorem a časovému harmonogramu jsme si cesty udržovali $z$ větší části sami. Protože jsme ale nedělali ekonomické operativní plány a nehlídali si náklady v reálném čase, bylo na konci roku už velice složité dožadovat se kompenzací.

Ve své práci se budu zaobírat tím, jakým způsobem by se tento problém dal řešit a představím vám software, který by tuto práci zjednodušil a také zefektivnil. 


\section{Ekonomické operativní plánování a plány}

Ekonomické operativní plánování je nejkomplexnější a také nejsložitější. Nejdůležitějším prvkem těchto plánů je sledování průběhu práce $v$ čase $v$ návaznosti na náklady. Je nezbytné si před vedením těchto plánů rozmyslet jaké aspekty a do jaké hloubky budeme jednotlivé činnosti sledovat. Je napřiklad zbytečné sledovat každý šroub či matku, která na stavbu príije. Naopak je vždy důležité sledovat mzdy, mechanizaci a hlavní materiály. U monolitických staveb to bude beton, výztuž a bednění u zděných zase malta, cihly atd.

Při vytváření plánu je nutné přemýšlet nad tím, aby nám plánování a jejich aktualizování plánů nezabíralo více času, než kolik nám mohou ušetřit.

\section{Ekonomické operativní plánování - vedení}

Při vedení plánů je nutné mít správné podklady. Mezi nejdůležitější patří časový plán projektu, projektovou dokumentaci, výrobní kalkulaci, stav kapacit (mechanizace, materiál, pracovníci atd....) a přehled provedených prací.

Pro vedení je vhodné používat kalkulační vzorec, přesněji její část. Z důvodu, že je operativní plán sestavován na stavbě, je nejlépe ho sledovat pouze z pohledu prímých nákladů - materiál, mzdy, stroje, OPN. Plánování režií a zisku je v tomto případě zbytečné a i nekontrolovatelné. Držíme se pravidla, že plánujeme a vedeme pouze to, co dokážeme později zkontrolovat.

Pro vedení je důležitý způsob a forma. Pouze zapisování nákladů formou zápisků nestačí. Velice důležité je při vedení ekonomického operativního plánu umět potřebu zařadit $k$ dané činnosti. Problém v př́ípadě, kdy nepřiřazujete potřebu $\mathrm{k}$ položce nastává při následné kontrole, protože nevíte jak a čím je potřeba využívána. Mohou poté nastat tyto dvě situace:

a) Náklady vám nevychází podle předpokladů, nevíte však z jakého důvodu.

Tím, že používáme stejné potřeby na různé položky dochází ke zmatkům.

Např́klad pokud mechanizaci používáte na více položkách, což je velice obvyklé, tak při kontrole nedokážete jasně přiřadit kdy byl jaký stroj na jaké činnosti používán. Nezbývá vám tudíž než sledovat a poté vyhodnocovat. Nejenom, že ztrácíte čas, ale i doba, kdy nedokážete jasně vyhodnotit na jaké činnosti je spotřebováno více dané potřeby je ekonomicky ztrátová.

b) Horším případem však bývá, když vám například mechanizace podle plánu vychází. Ale je to $z$ toho důvodu, že někde tuto potřebu využíváte méně a někde zase více. Problém však nastává v časovém horizontu, kdy činnost nebo činnosti, kde mechanizaci využíáte méně, skončí a dobíhá vám činnost, která mechanizaci využívá více než jste plánovali. Toto zjištění však většinou přichází pozdě a vy už nemáte dostatek času ke změně technologie či změny vůči investorovi.

Mezi nespornou výhodou přiřazovat potřeby do jednotlivých položek je lepší orientace při vytváření výrobní kalkulace. Na stavbách je často zvykem dělat výrobní fakturu podle procent udělané práce. Jestli však fakturujeme částku vyšší či nižší než náš náklad, bývá často otázkou. 


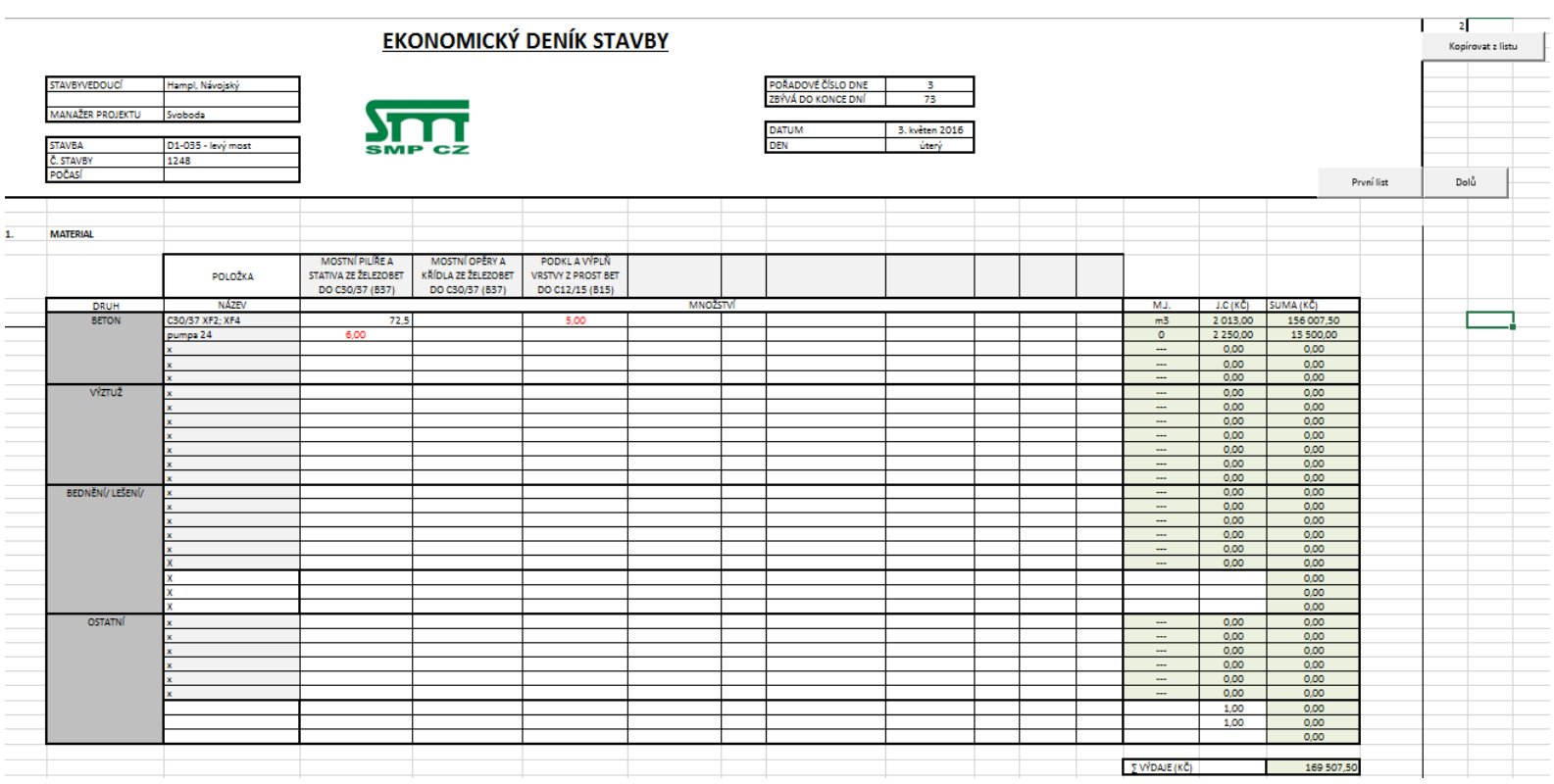

Obr. 3 Ekonomický deník- zápis materiálu

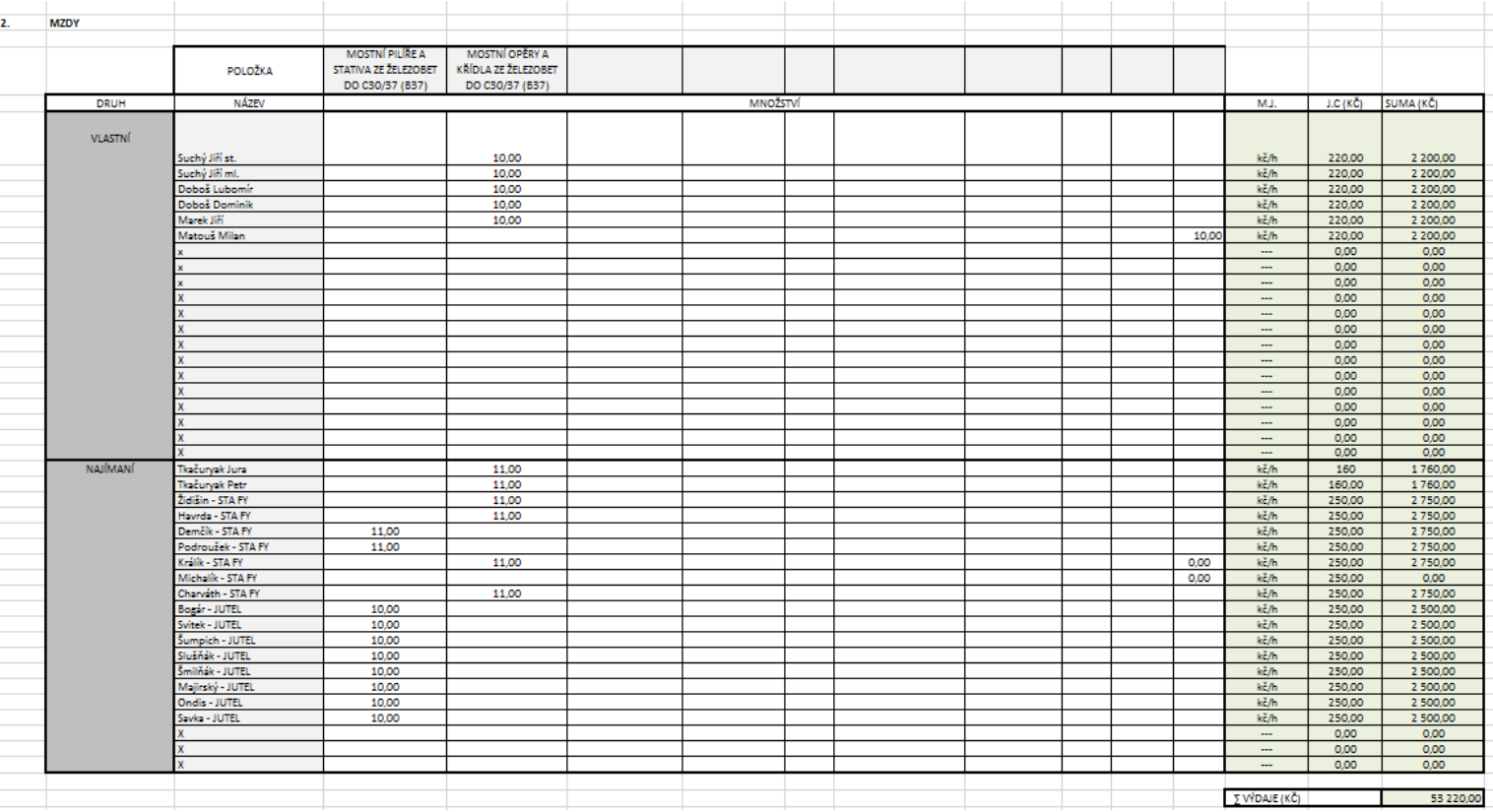

Obr. 4 Ekonomický deník- zápis mezd 


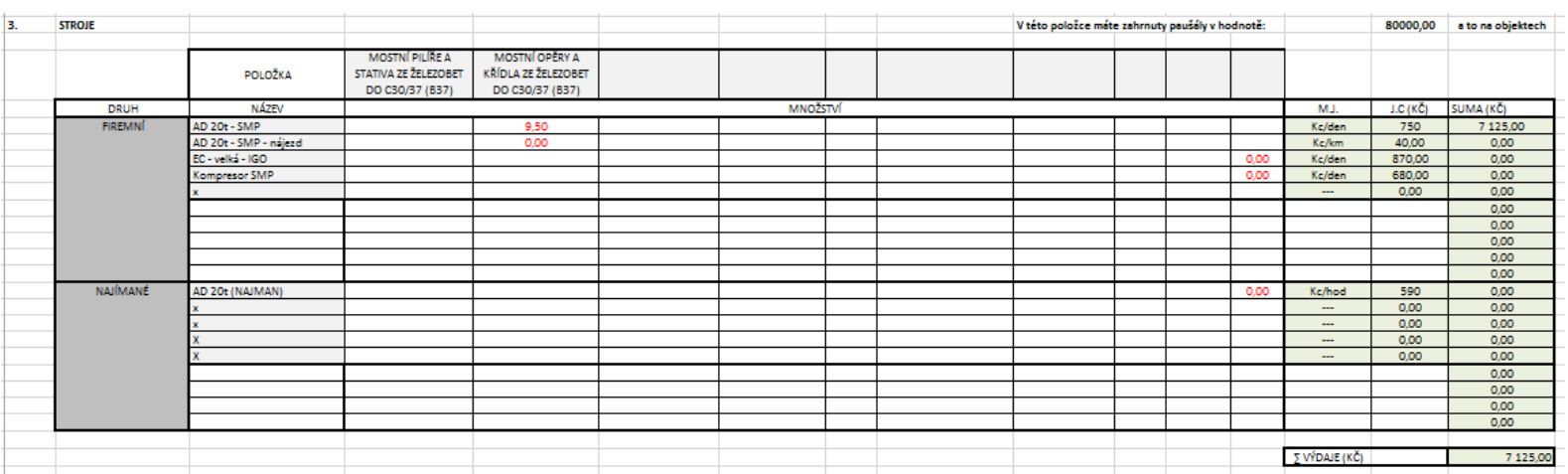

Obr. 5 Ekonomický deník- zápis mechanizace

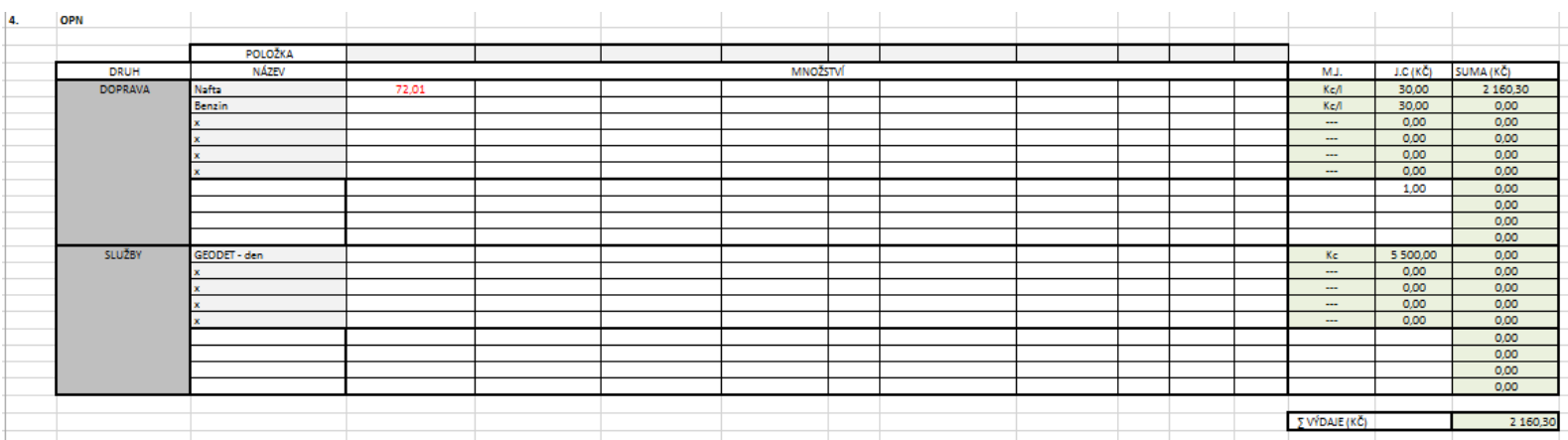

Obr. 6 Ekonomický deník- zápis OPN

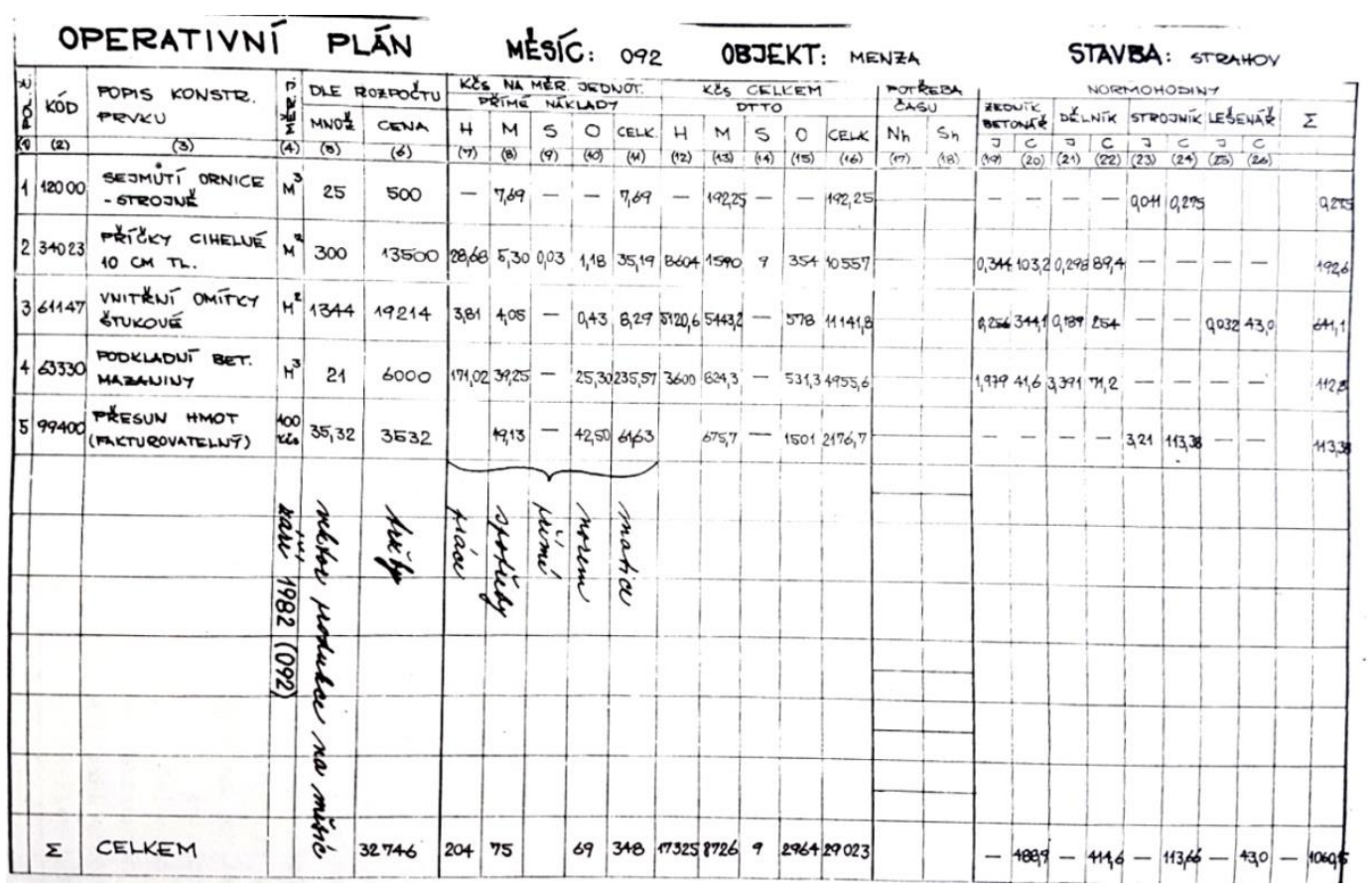

Obr. 7 Operativní plán - zápisy papírová podoba 


\section{Chyby vyskytující se při vedení ekonomického operativního plánu}

Mezi největší chyby při vedení ekonomického operativní plánu bývá zaobírání se přilišnými detaily. Není možné sledovat veškerý materiál či stát za dělníky a psát přesné normohodiny. Další chybou bývá sledování činností, které nelze přiřadit př́mo k položce v soupisu prací. Pro ekonomické sledování je nutné používat naceněné položky.

\section{Ekonomické operativní plánování - kontrola}

Pro kontrolu ekonomického operativního plánu je nutné znát předpoklady, které jsou určeny na začátku kontroly. Předpoklady vycházejí z časového plánu prací a výrobních kalkulací.

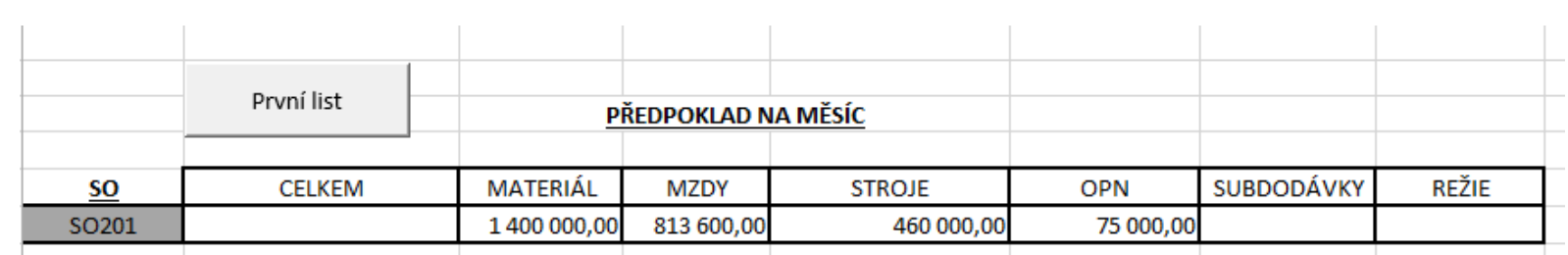

Obr. 8 Vyplnění předpokladů na měsíc

Vyhodnocení a kontrola operativních plánů by měla probíhat každý týden. Není nutné sledovat a vyhodnocovat plán po položkách. Vždy záleží na míre podrobnosti, kterou si na začátku stavby zvolíme. 


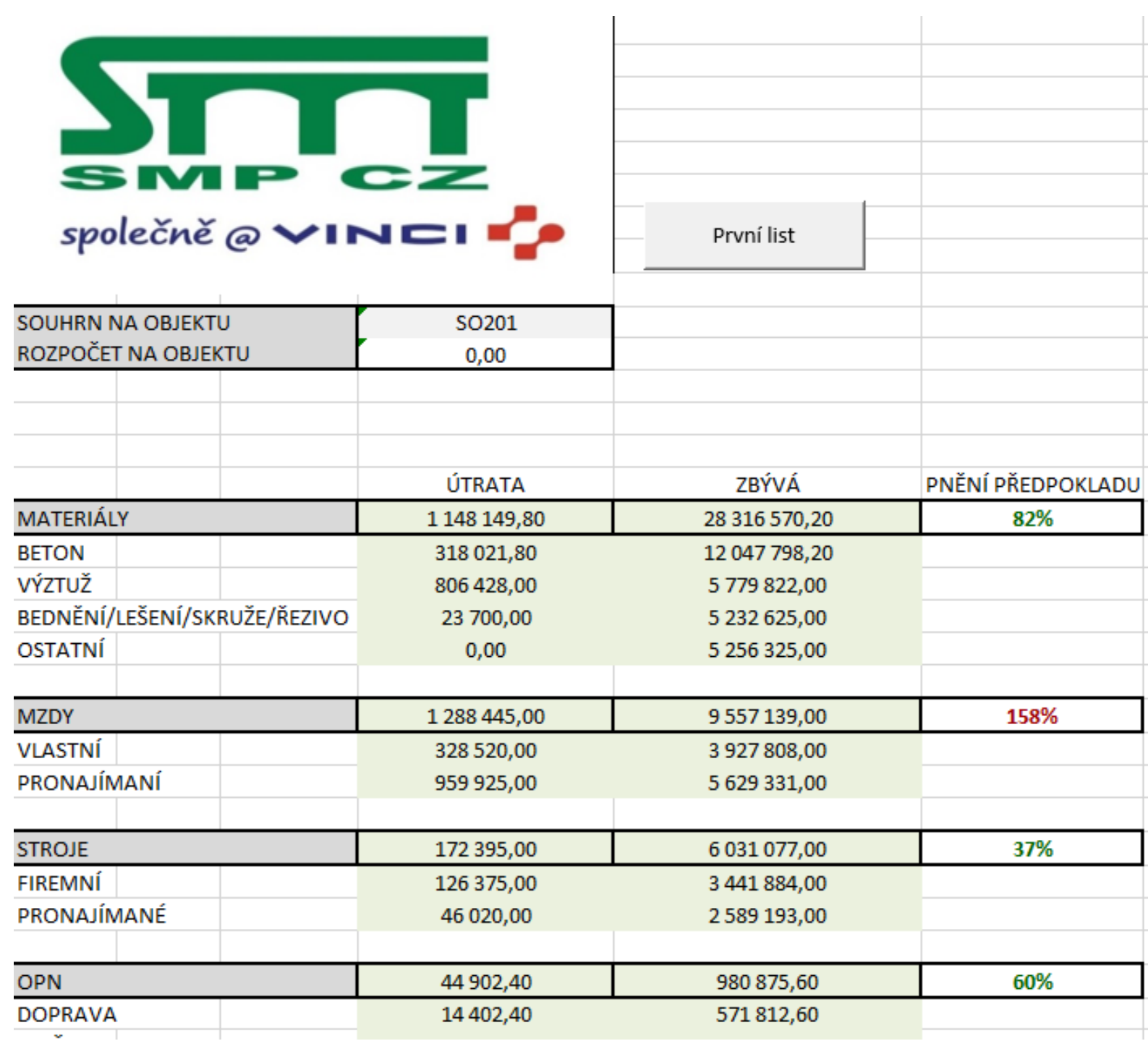

Obr. 9 Kontrola předpokladů v ekonomickém deníku

Každá kontrola by měla být vyhodnocena. Je nutné si z každé kontroly uvědomit, proč nebyl předpoklad splněn. Není vždy pravda, že pokud byl předpoklad vyšší, než náš reálný náklad tak šetříme. Je možné, že jsme utratili za mechanizaci méně kvưli tomu, že jsme neudělali práci, kterou jsme měli naplánovanou. Naopak na mzdách jsme utratili více z důvodu prací, které nebyli na začátku měsíce plánovány. Proto by se kontrola nákladu podle operativního plánu měla kontrolovat i v závislosti na harmonogramu. 


\section{Plán}

\section{Návrhy ke zlepšení}

\section{Vyhodnocení}

Sledování pánu
Kontrola

plánu

Obr. 10 Popis kontroly

\section{Chyby vyskytující se při kontrole ekonomického operativního plánu}

Při kontrole operativních plánu se často sklouzává pouze na porovnání nákladů s předpokladem bez návaznosti na harmonogram. Je nutné při každé kontrole si uvědomit propojení nákladu na činnosti v čase. Opravdové ušetření znamená, že je splněna podmínka menších nákladů s předpokladem při udržení stejného časového harmonogramu. 


\section{Závěr}

V této 1. části jsem popsal ekonomický operativní plán a věnoval jsem se chybám při tvoření plánů. Pomocí správného plánu nejenže snižujeme časový skluz předávání informací, ale zároveň má ekonom lepší ekonomické ponětí o stavbě v reálném čase.

$$
\text { 7-10 dní }
$$

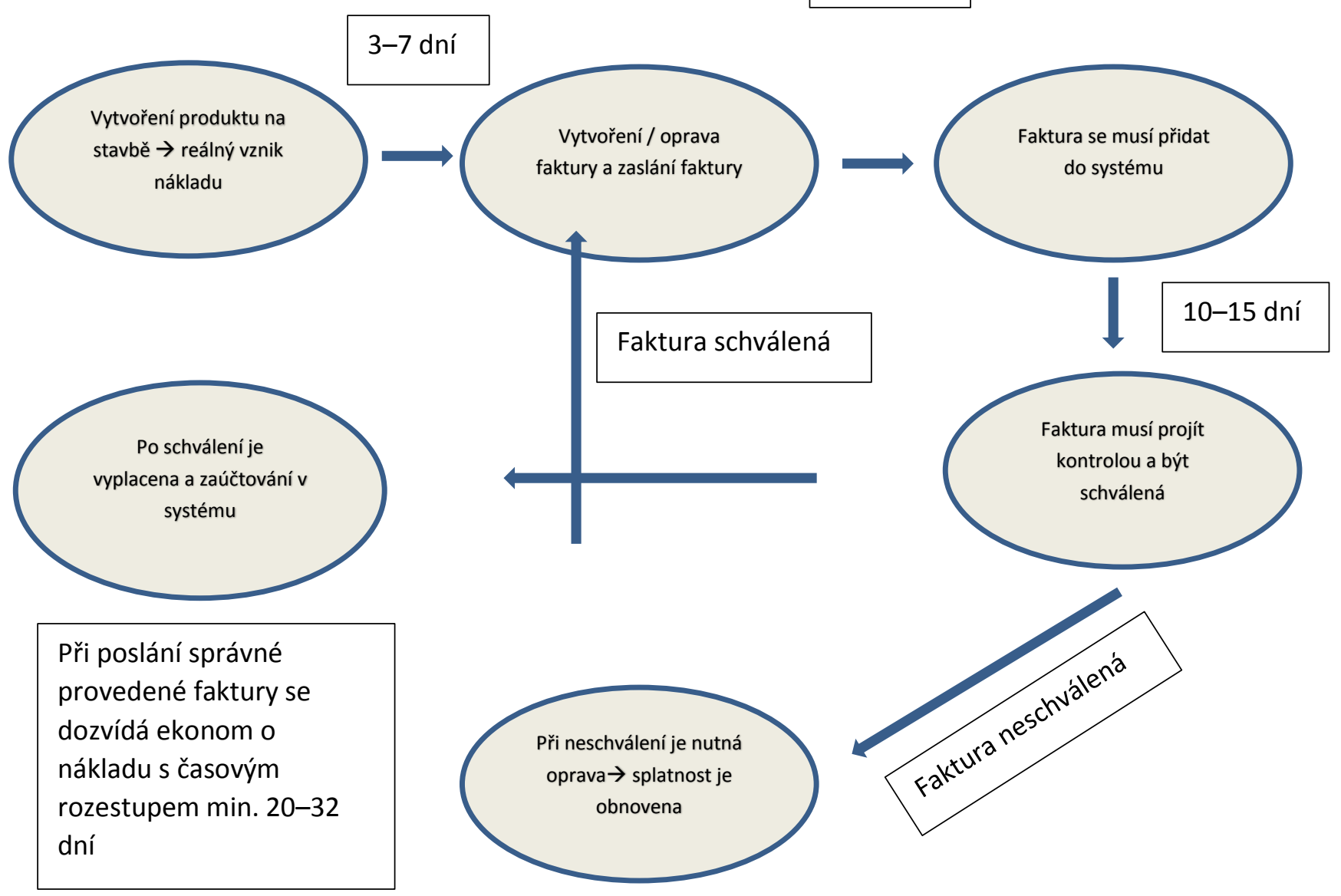

Obr. 11 Model bez operativního ekonomického plánu 


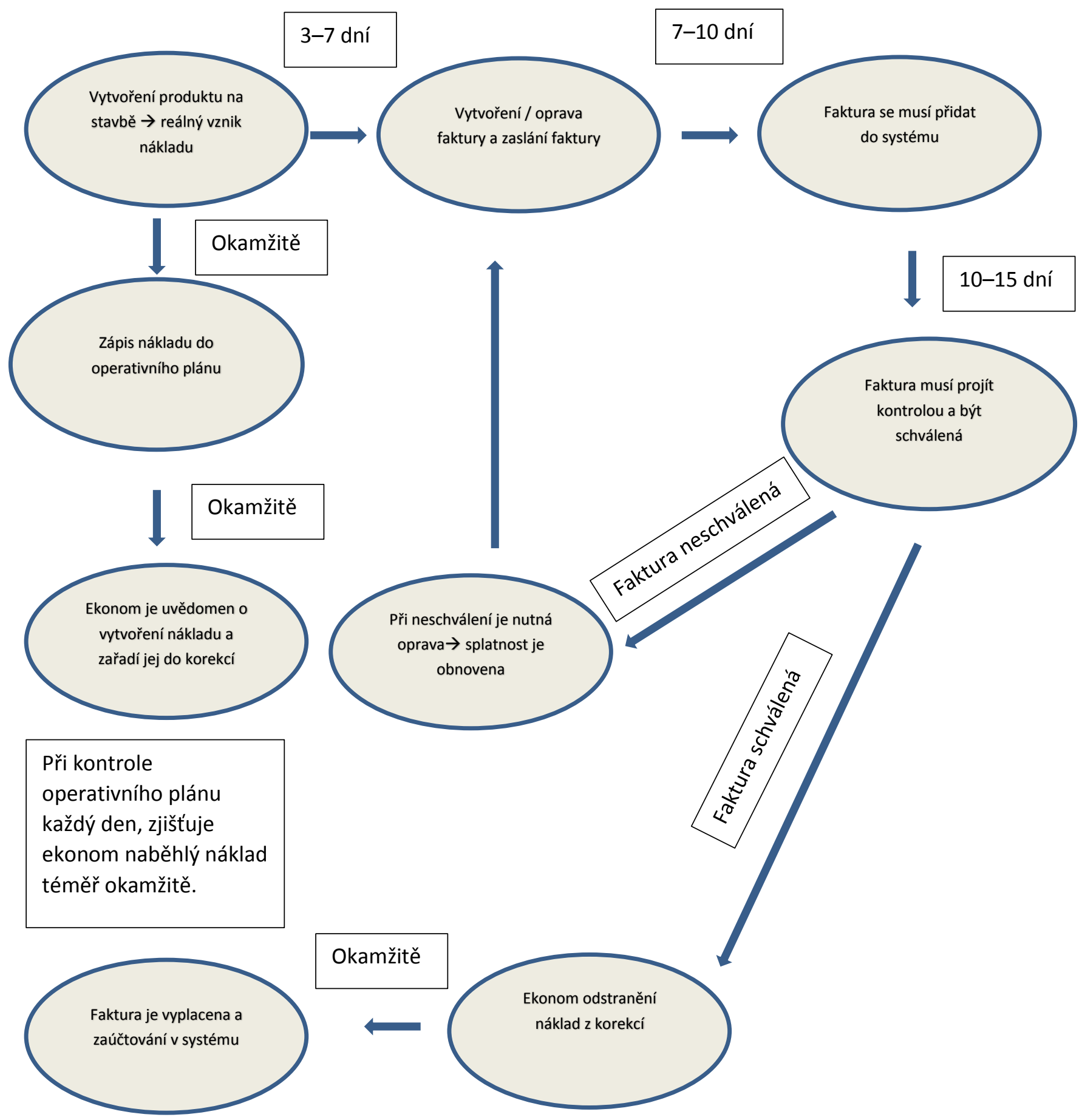

Obr. 12 Model se sdíleným operativním plánem 
Je důležité snižit časový skluz informací na minimum. Je nutné problémy na stavbě řešit $v$ čase vzniku, a ne s časovým odstupem někdy až třicet a více dní.

Správně vedený operativní plán zlepšuje:

Predikci nákladů a časové náročnosti

Snižuje časový skluz informací

Zefektivňuje operativu na stavbě

Přináší rád a jednotnost vedení

Zpřesňuje korekce

Zrychluje a zpřesňuje práci ekonoma

Pro takovéto vedení by bylo nejlepší vytvoření softwaru, který by toto vše umožňoval. $V$ rámci práce ve firmě SMP CZ jsem na stavbě pocitoval nutnost takového softwaru, který by nebyl uživatelsky složitý, a proto jsem vytvořil ekonomický deník.

Důvod vzniku takového deníku bylo hlavně z důvodu:

Problémové vedení ekonomie na stavbě

Potřeba hlídání peněz

Nefungující deník mistra

Sledování ekonomie a plnění předpokladů na stavbě

Jednal se o Excel, kde jsem již zakomponoval některé poznatky z ekonomického operativního plánování:

Řazení potřeb př́mo pod položky

Používání rozdělení podle kalkulačního vzorce

Plánování pomocí předpokladů

Rychlé a jednoduché prostředí

Pomocí naprogramovaných maker jsem vytvořil Excel, který jsme použili na stavbách jako byli Rekonstrukce a rozšiření mostu D1-035 v km 29,161 dálnice D1, Bezbariérové zpřístupnění stanice metra Anděl, výstavba mostů na silnici l/11 Nebory - Oldřichovice či rekonstrukce stanice metra Jinonice.

Za tento Excel jsem následně vyhrál také cenu inovace skupiny SMP CZ v kategorii Management.

Jaké byly tedy výsledky při použití tohoto Excelu:

Zlepšení kontrol nákladů

Zlepšení predikcí na další měsíc

Zpřesnění korekcí

Snižení času při vytváření výrobních faktur

Snížení a udržení nákladů podle plánu

Zlepšení komunikace mezi ekonomem a stavbou 


\section{Ekonomický deník}

Jedná se o software pro zaznamenávání denních záznamů. Ve formě Excelu s makry nebo webovém rozhraní.

Jelikož se jedná o Excelový sešit s makry, je nutné je po otevření sešitu povolit.

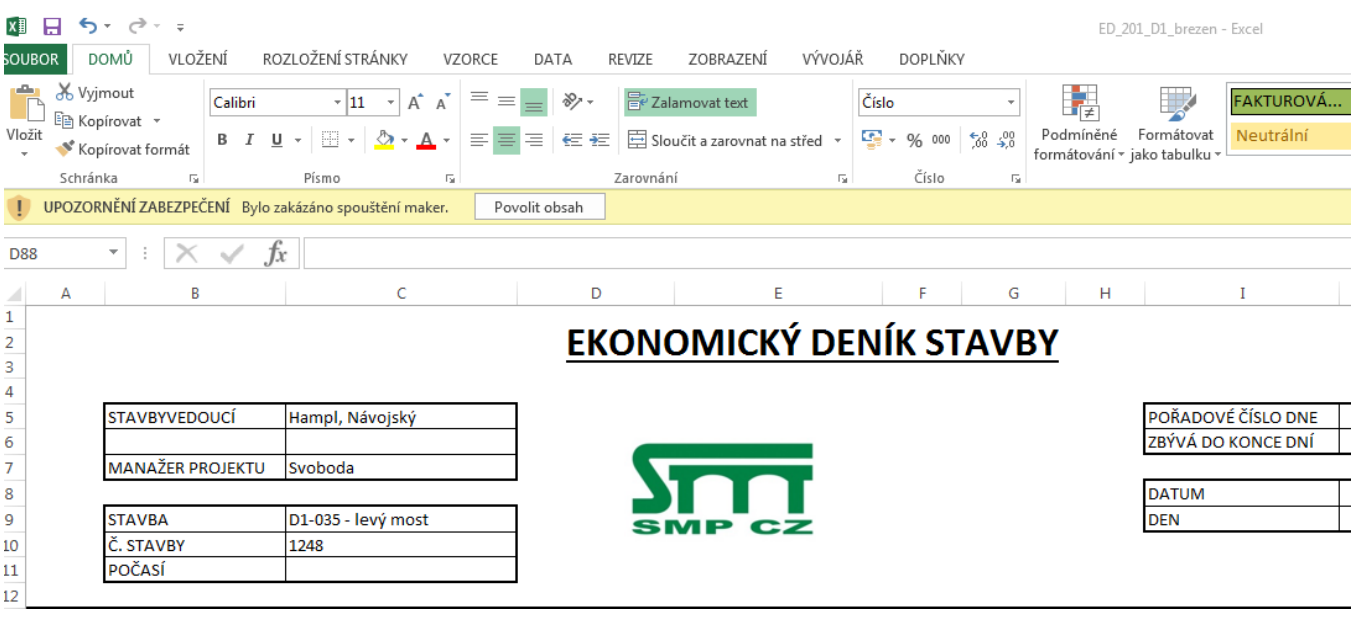

Obr. 13 Povolování maker v Excelu

\section{Príprava}

1) Vyplnit si
a) Titulní stranu
b) Databáze potřeb
c) Soupis prací

2) Vypočítat a vyplnit si paušální poplatky

3) Vyplnit si titulní stránku

Prostředí programu je jednoduché a jelikož se jedná o Excel, tak i velice známé. 


\section{Vedení}
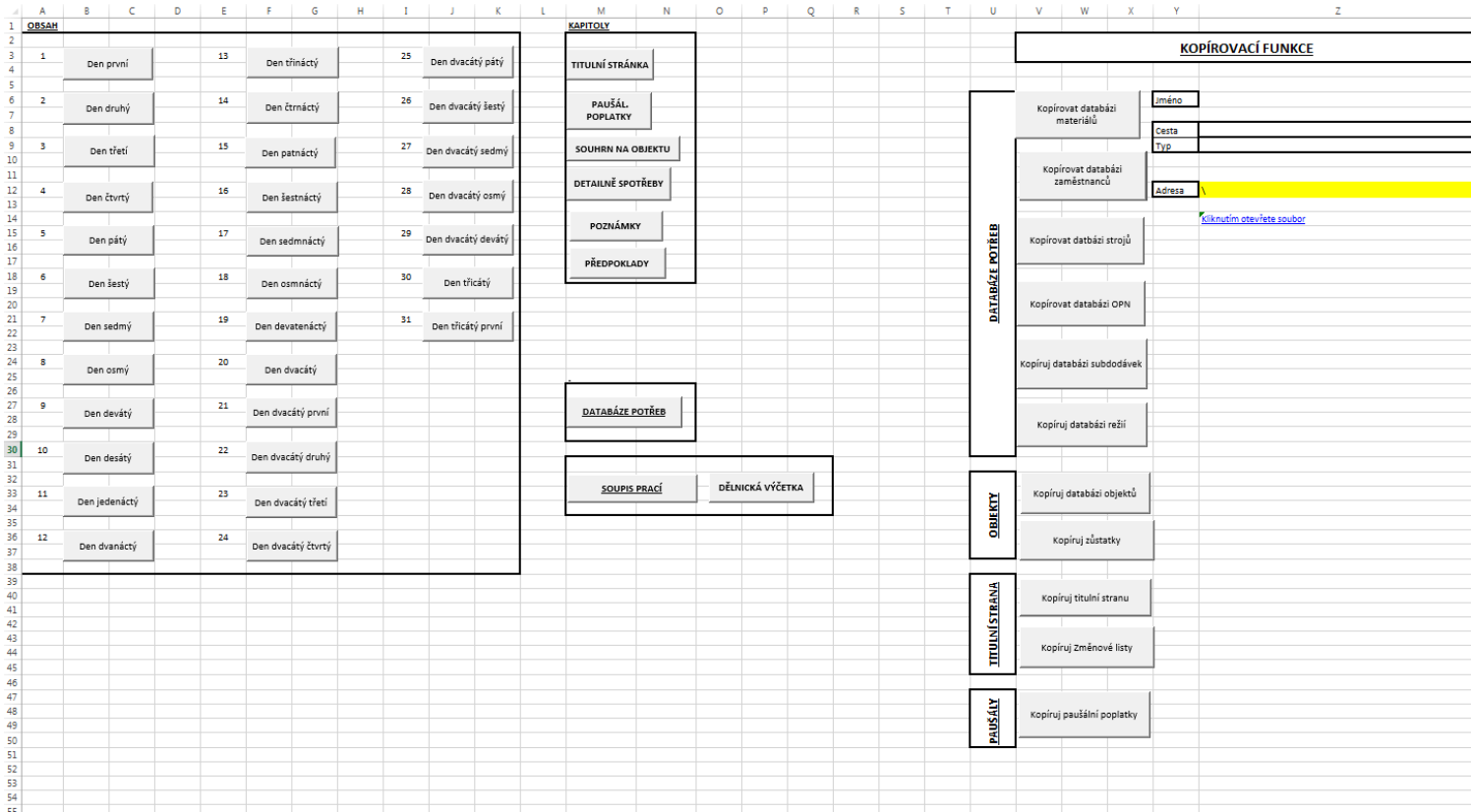

Obr. 14 První list programu
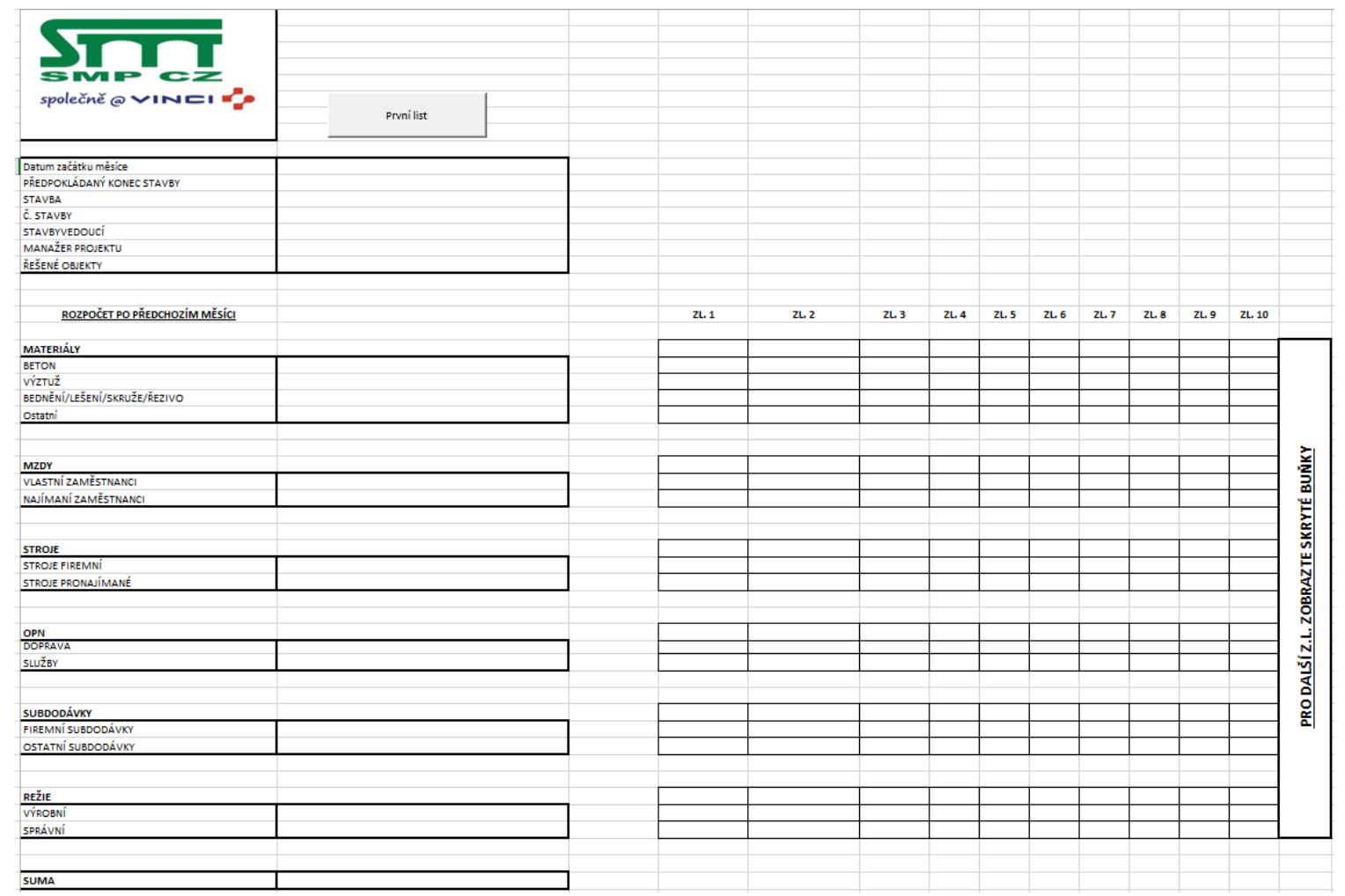

Obr. 15 Titulní strana

Při zakládání nového projektu, je vždy nutné si vyplnit titulní stranu. Na této stránce se vyplňují základní údaje stavby.

Každý sešit se zakládá pro zvláštní stavební objekt. 
Na začátku stavby je důležité vyplnit si rozpočet na materiály, mzdy, stroje, OPN. Tyto informace se vyplňují pouze na začátku stavby, do dalších měsíců se poté již nahrávají automaticky.

Do kolonek pro ZL se zapisuje částka, o kterou se předpokládá zvýšení nákladu. Tato funkce se používá $v$ průběhu stavby, kdy je například zřejmé, že na materiálech, např́klad na betonech, nevystačí uvažovaný rozpočet z důvodu více prací.

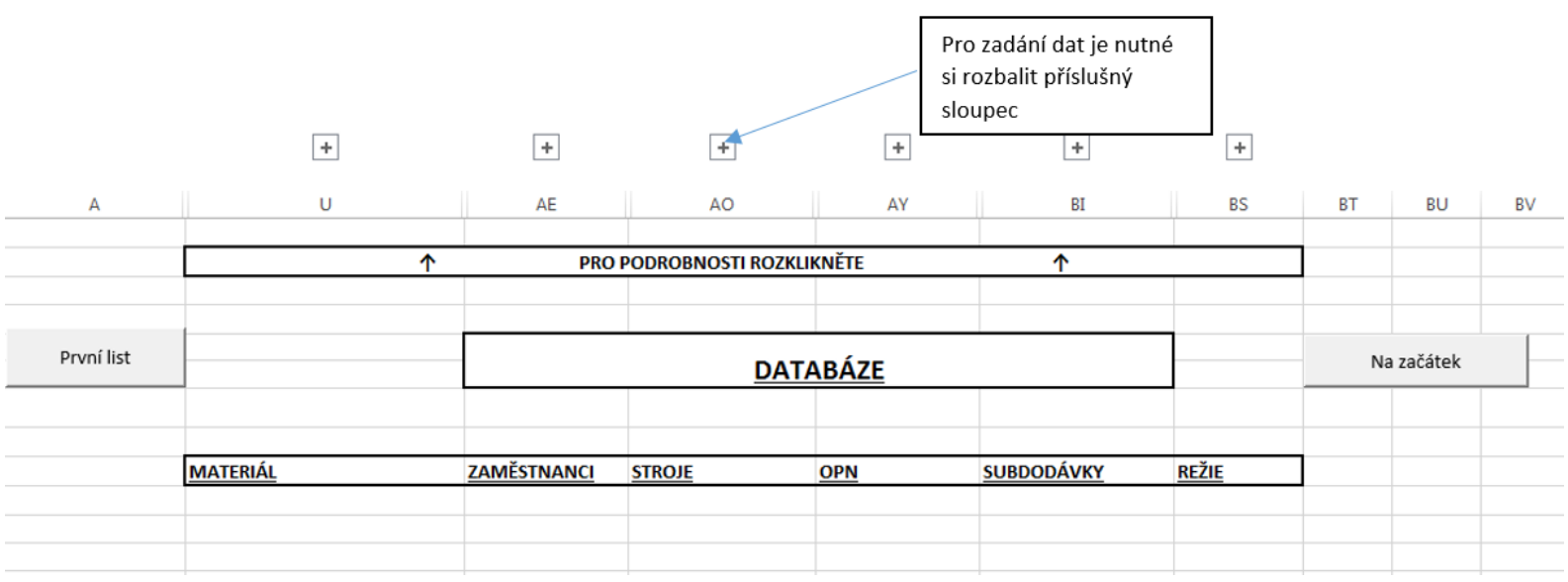

Obr. 16 Databáze potřeb

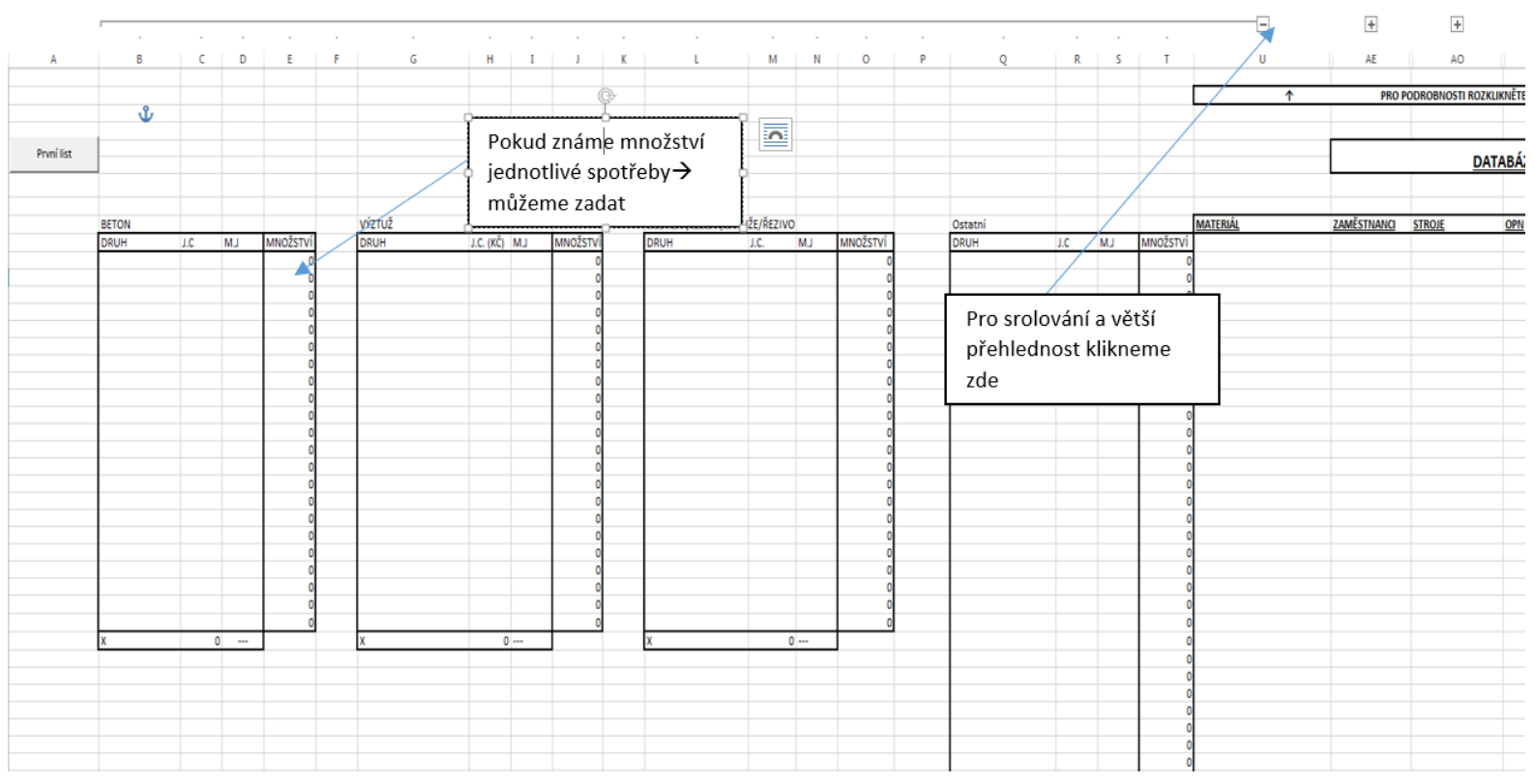

Obr. 17 Databáze potřeb - vyplňování

Databáze potřeb se vyplňuje s pomocí ekonoma. Zde se vypiši jednotlivé potřeby, které se budou na stavbě a daném objektu vyskytovat. Je nutné, aby zadání jednotkových cen vycházelo ze smluv a objednávek. Tato databáze je kdykoliv př́stupná a je možné si ji doplňovat i během výstavby. 


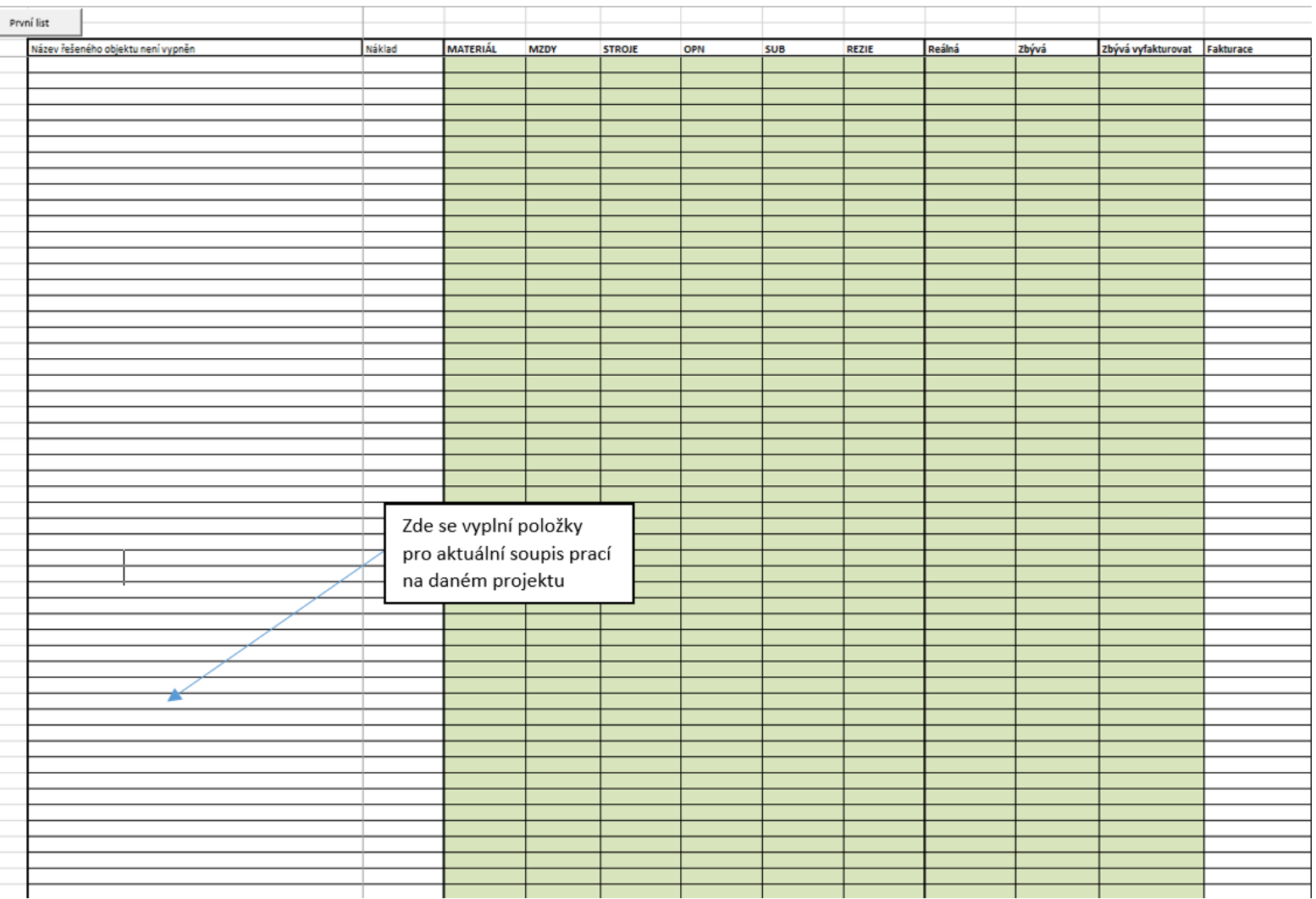

Obr. 18 Soupis prací

Tento list se vyplňuje s pomocí ekonoma. Položky by měli být stejné jako položky ze soupisu prací pro daný objekt. Na tomto listu také uvidíte aktuální spotřebu na daných položkách a v rozkladu na materiál, mzdy, stroje a OPN.

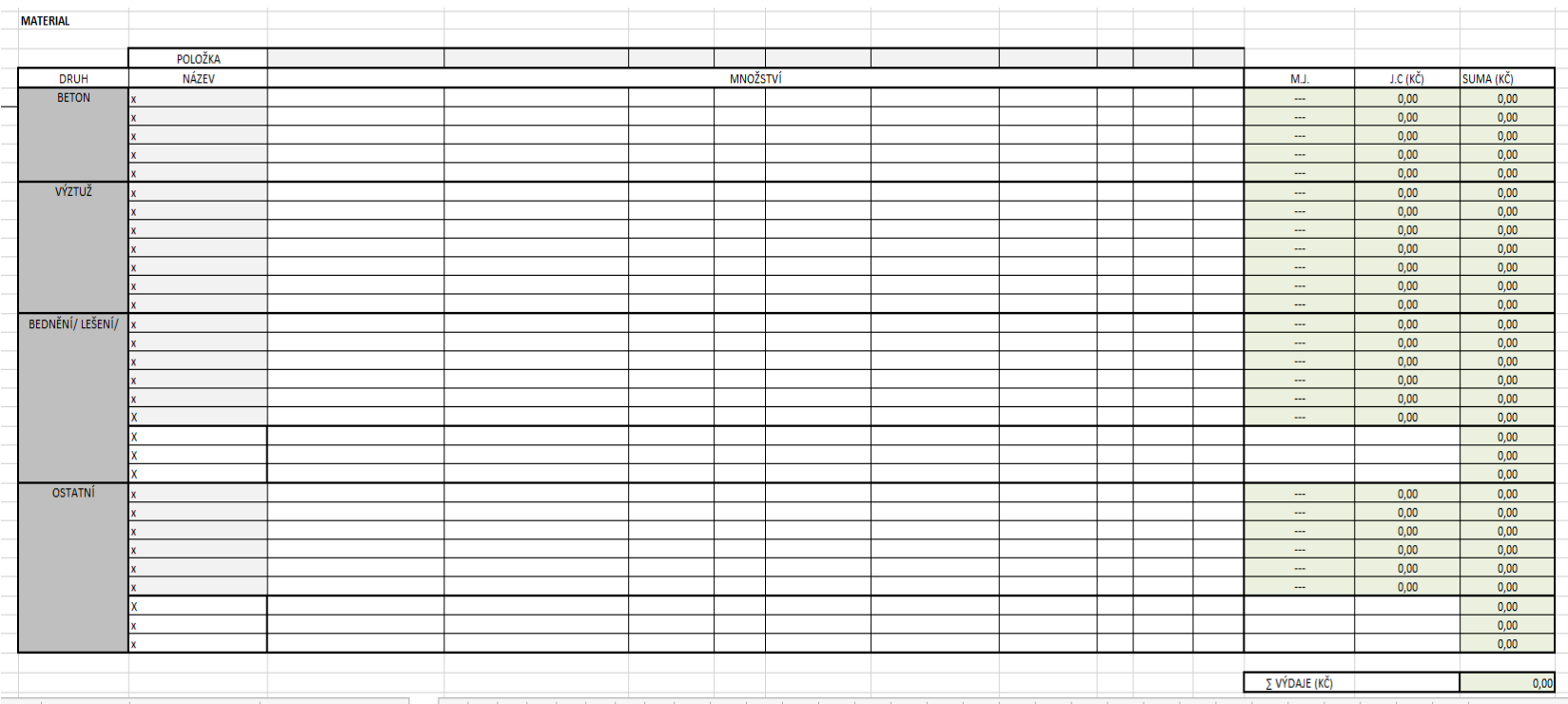

Obr. 19 Denní záznamy

- Každý den si stavbyvedoucí/hlavní stavbyvedoucí otevře př́slušný list podle čísla dne a vyplní si tabulky 
- V V každé tabulce se pečlivě navolí položka ze soupisu prací, která odpovídá př́slušné vykonané práci v daném dni

- Pod položkou se navolí dané potřeby potřebné k vykonání práce

- Veškeré potřeby, jejich jednotkové ceny a měrné jednotky se zobrazují z databáze potřeb

Druhy tabulek
a) Materiál
b) Mzdy
c) Stroje
d) OPN

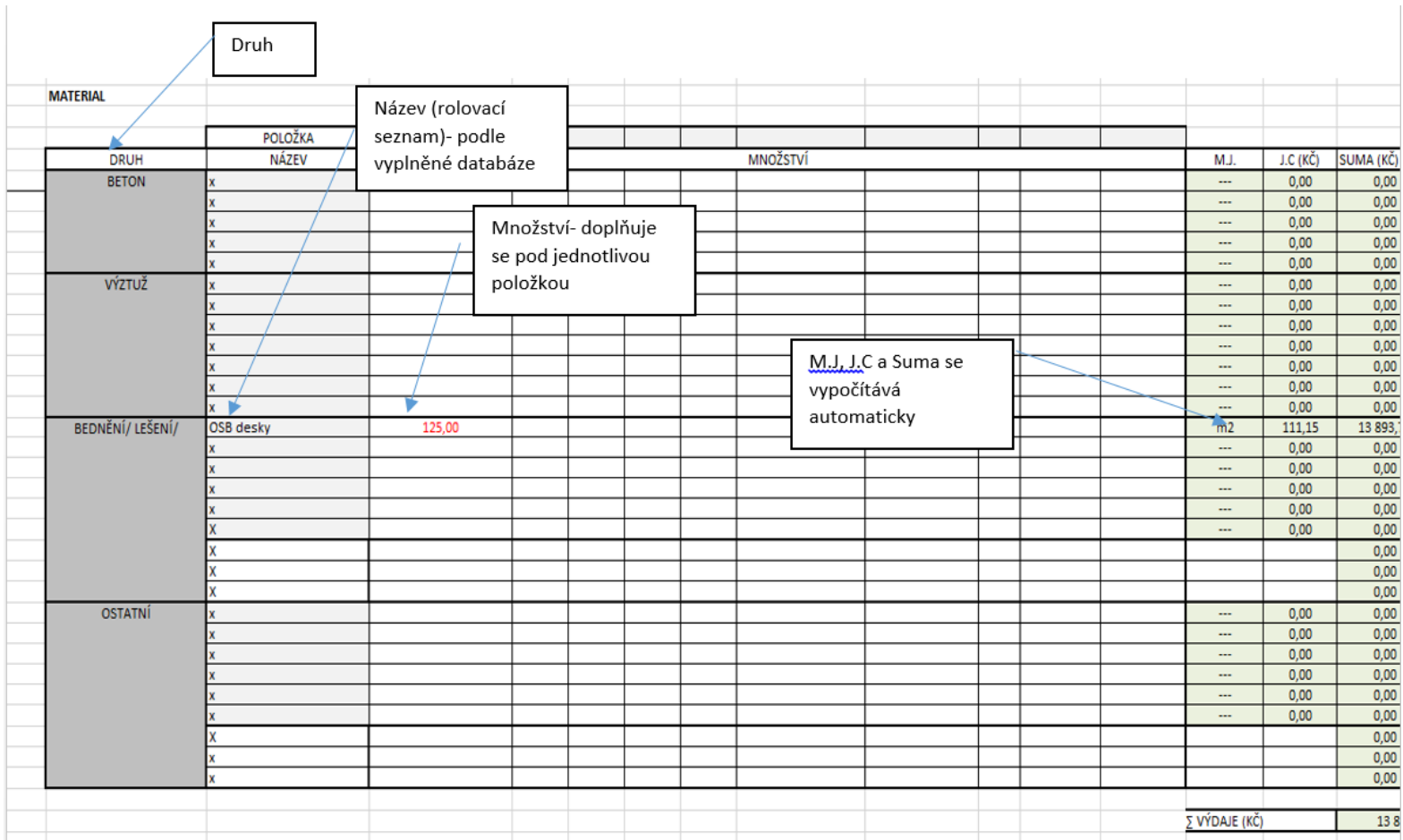

Obr. 20 Tabulky v listech ekonomického deníku

\section{Výstupy}

Souhrn měsíce - na tomto listu najdete souhrn na objektu za daný měsíc, kolik se za daný měsíc utratilo na materiálu, mzdách, strojích a OPN.

Soupis prací - na tomto listu najdete ekonomický souhrn podle kalkulačního vzorce po položkách.

Detailně spotřeby - na tomto listu se Ize podívat kolik a jaké potřeby se spotřebovali.

Dělnická výčetka - na tomto listu si můžete podívat kdo, kolik a jaký den odpracoval hodin. 
Již při tvoření Ekonomického deníku jsem však narážel na některé problémy, které byli kvůli prostředí programu Microsoft Excel složitě řešitelné či přímo neřešitelné. Mezi hlavní problémy například patřilo lepší a rychlejší sdílení, tento problém se řešil pomocí sdílené složky v rámci firemního intranetu. Otevírání a ukládání však někdy trvalo stejně dlouho jako zápis. Dalším problémem byl vytváření roli s právy pro větší přehlednost. Také se kvůli rychlosti nedalo v jednom excelu naprogramovat více než jeden stavební objekt. Proto existoval ekonomický deník pro každý stavební objekt zvlášt' a na každý měsíc.

Díky těmto poznatkům jsem se rozhodl napsat novou verzi ekonomického deníku, který by splňoval požadavky jak pro operativní plánování, tak i pro moderní nástroj na vedení a rrízení stavby. 


\section{Ekonomický deník verze č. 2}

Některé problémy, které byly způsobeny volbou prostředí programu Microsoft Excel jsem již zmiňoval. Mezi další nevýhody byla složitá implementace práv a pomalejší sdílení. Rozhodl jsem se proto, že tento program přesunu do nového prostředí. Vybral jsem si nakonec prostředí webové aplikace programovanou pomocí skriptovacího jazyka PHP a podporou Netteframework. Na databáze jsem použil jazyk MySQL.

Díky tomu vzniklo nové prostředí se zachováním hlavních funkcí Ekonomického deníku.

Nyní je možné vytvářet různé role a přiřazovat práva. Manager projektu např́klad nemůže dělat zápisy a mistr zase tvořit plány. Každá role má poté své přihlašovací jméno a heslo.

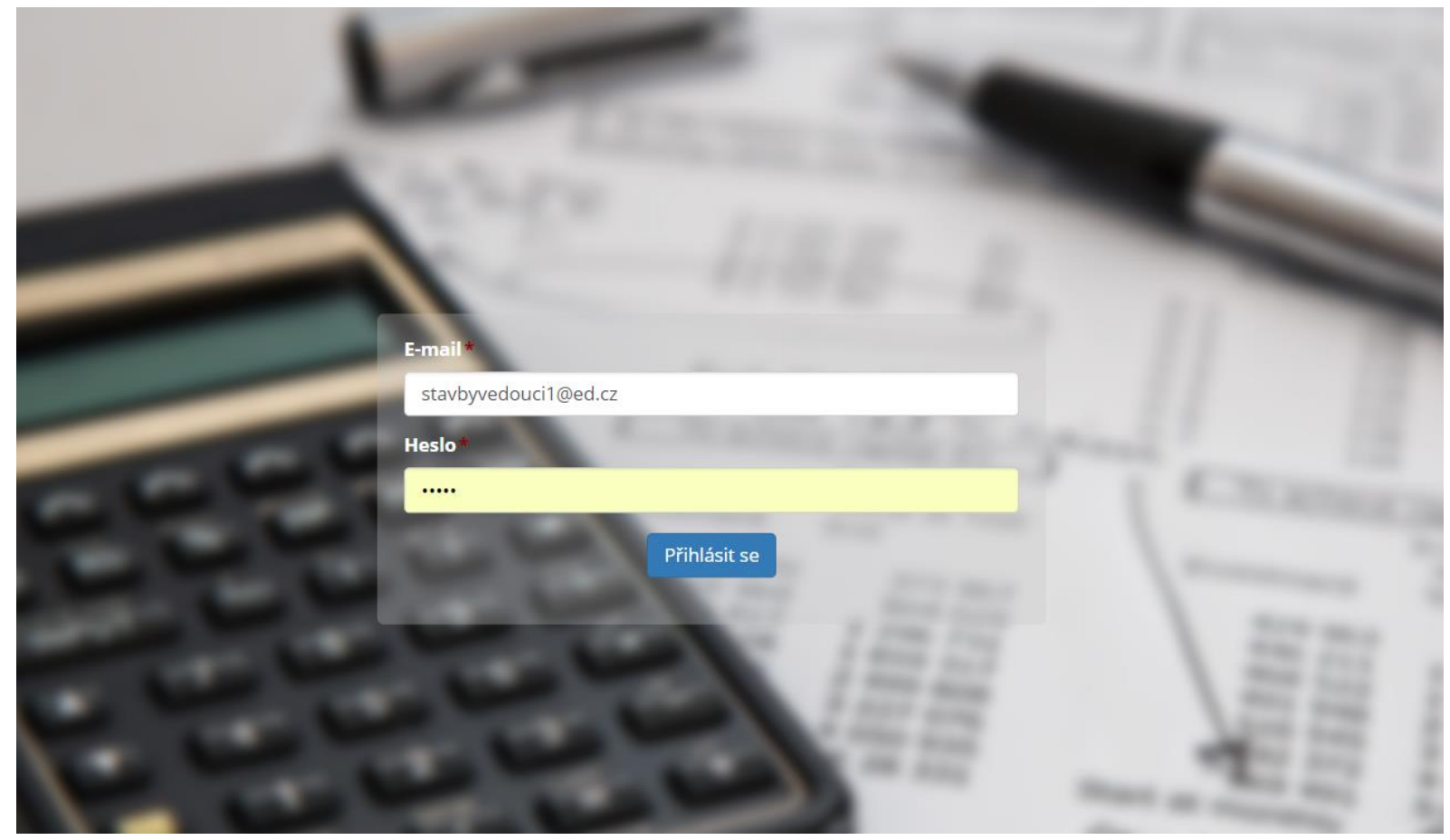

Obr. 21 Přihlašovací stránka

Manažer může sledovat všechny záznamy a vytvářet role stavbyvedoucího a dozoru. Role dozoru může pouze sledovat záznam ve stavebním deníku. Toto je nová funkce, která generuje z operativních záznamů záznam stavebního deníku. Stavební deník je proto online a kdykoliv př́stupný dozoru a investoru. Záznam se tvoří automaticky, tudíž odpadá práce se psaním stavebního deníku.

Do záznamu jde také nově nahrát fotku, která se automaticky přidá jako príloha $k$ zápisu do stavebního deníku. 


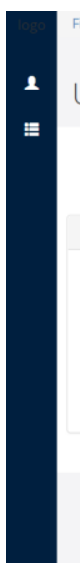

Firmy: firma 1

Uživatelé

Starbyededuci

Email

headiffirma1.ce

Jméno a prírimen

Jakub Novotny

head2@firma1.cz

(n)

Obr. 22 Správa uživatelů

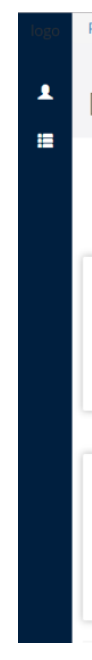

Projekty: Projekt 1 / objekty: object 1

Denní záznam

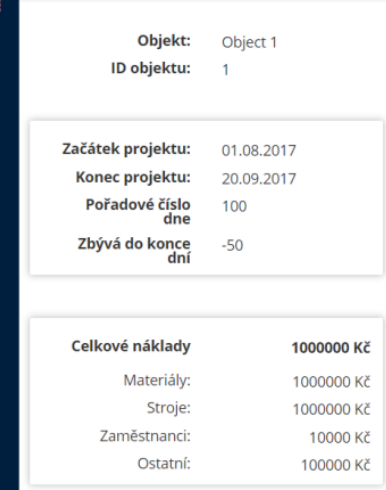

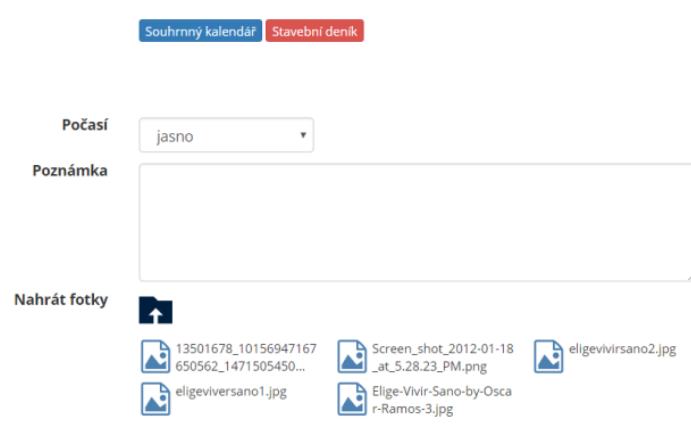

“ Listopad 2017

Po Út St Čt Pá So Ne

$\begin{array}{lllllll}30 & 31 & 1 & 2 & 3 & 4 & 5\end{array}$

9

13

$\begin{array}{lll}10 & 11 & 12\end{array}$

Obr. 23 Denní záznam

Díky změně prostředí také dokážeme nyní vést $v$ jednom účtu všechny projekty a jejich stavební objekty zároveň.

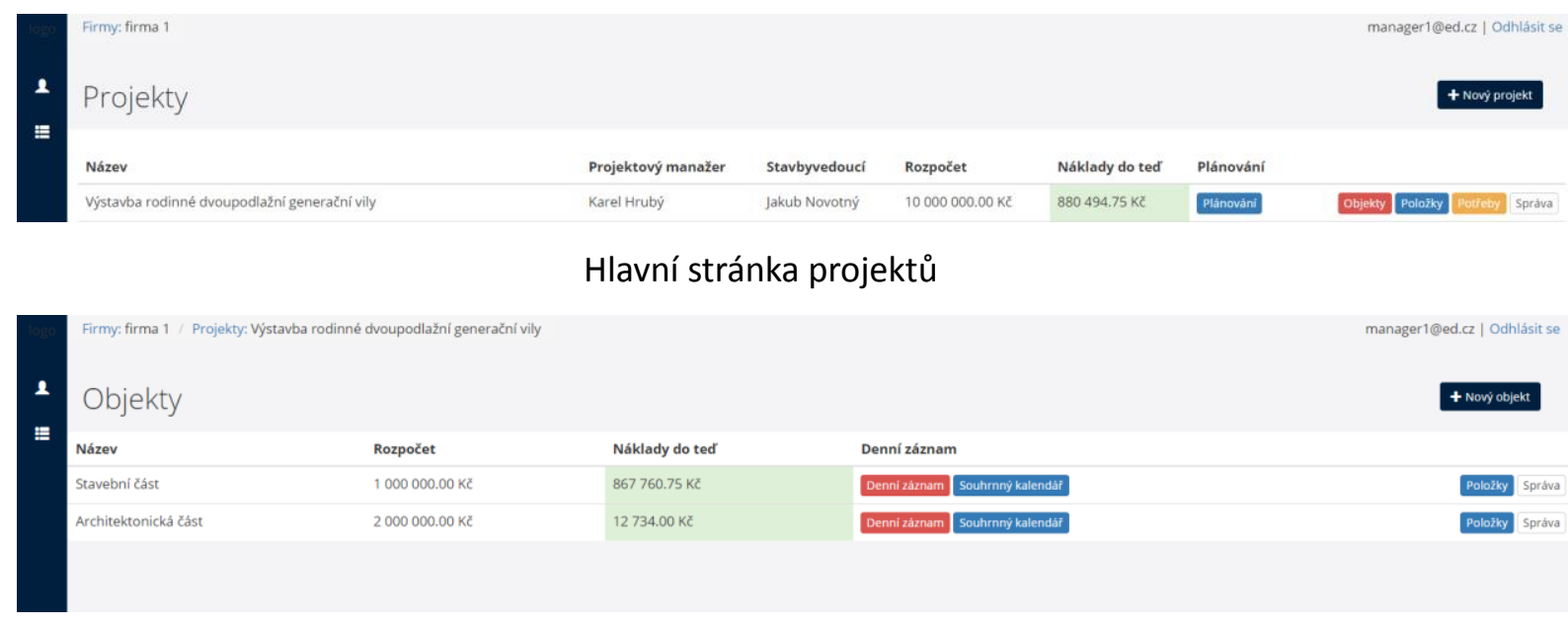

Obr. 24 Hlavní stránka objektů

Funkce tvoření databáze, přidávání položek a potřeb zůstala stejná jako v Excelu. Vytváření a doplňování záznamů zůstalo také stejné. 


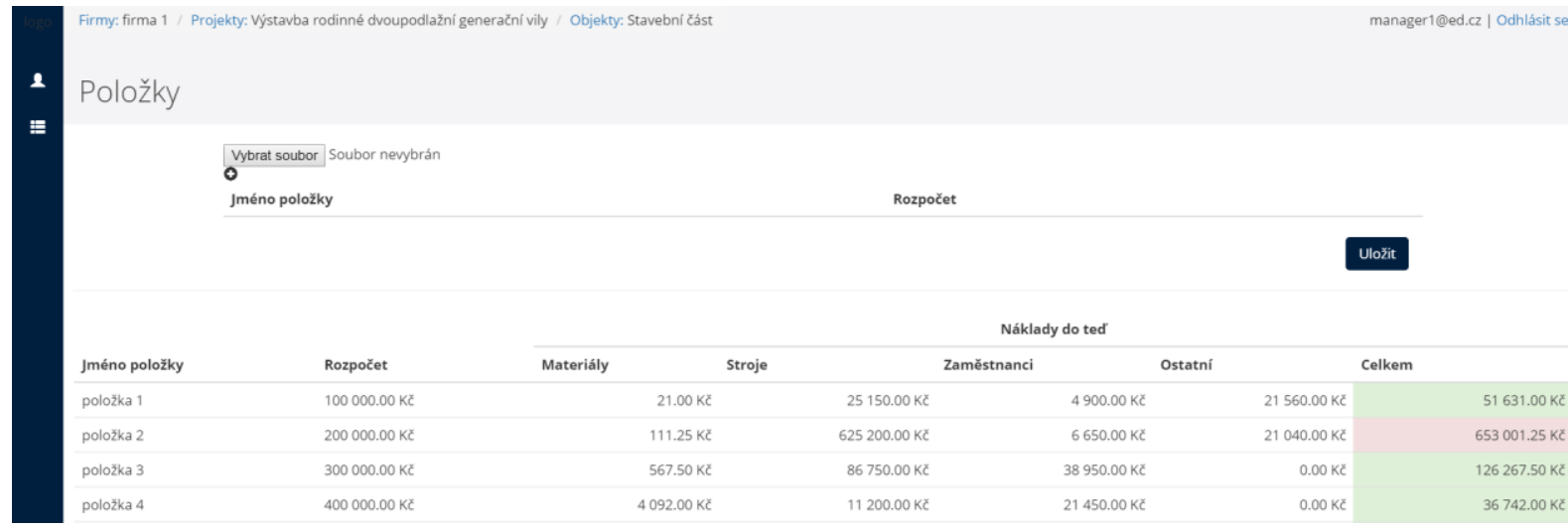

Obr. 25 Databáze položek

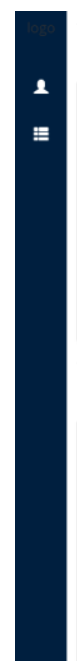

Materiály

Materiály

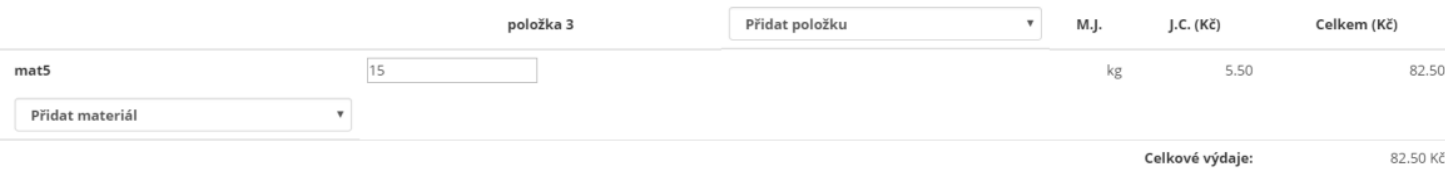

Stroje

Vlastni stroje

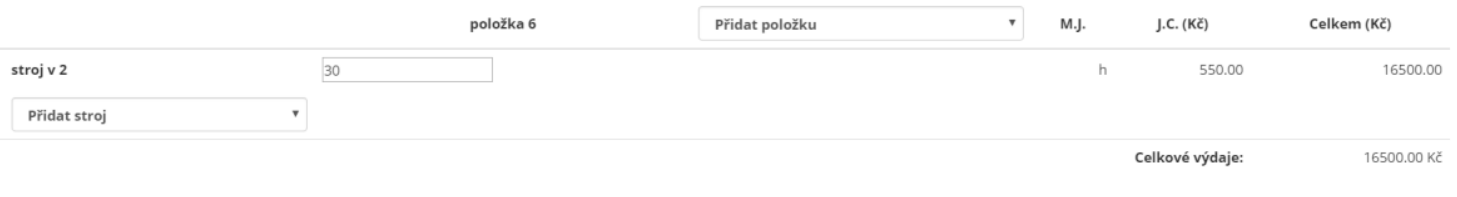

Obr. 26 Zápis potřeb

Co je však nové, je funkce vytváření plánů a jejich sledování. Nyní jsme schopni pomocí filtrů plánovat do úrovně jednotlivých potřeb. Díky novému rozhraní se dají nyní vyfiltrovat všechny záznamy o betonáži za určené období, či využití jednotlivých strojů na dané položce. Možnosti jsou téměř neomezené.

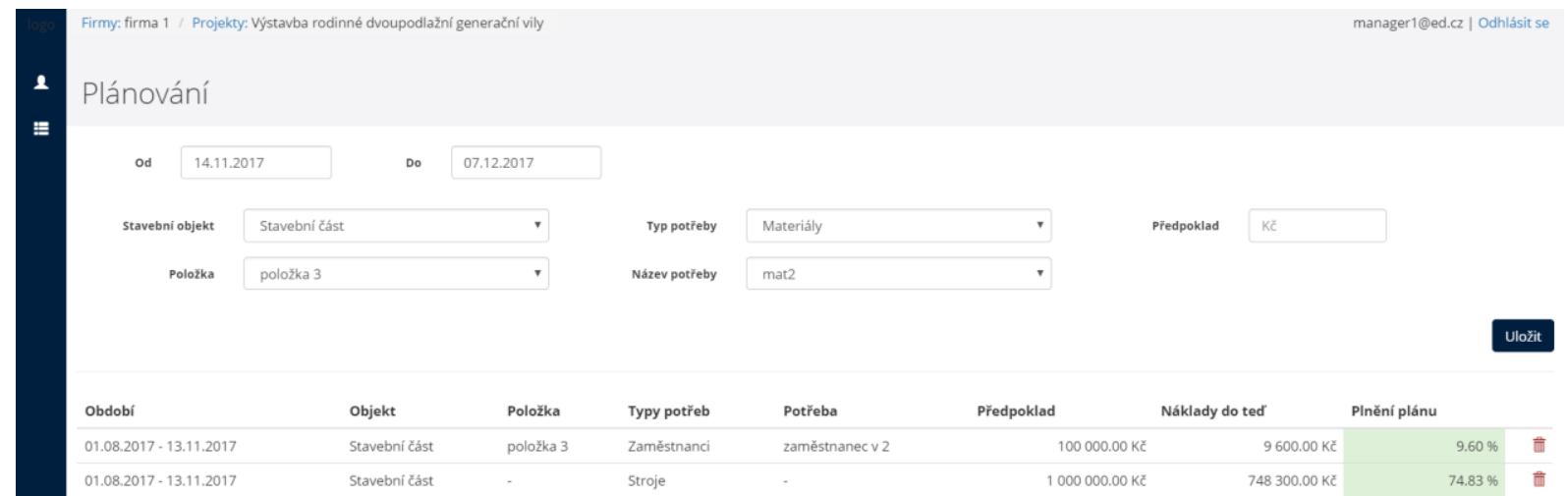

Obr. 27 Hlavní stránka plánování 


\section{Vyhodnocení}

Změna prostředí programu prospěla. Program je nyní vyspělejší a má mnohem více funkcí. Pomocí stejného vyplňování dat získáváme podstatně více informací, které jsou přehlednější.

Kromě funkcí, které známe ze starého Ekonomického deníku:

Souhrn měsíce - kde najdete souhrn na objektu za daný měsíc, kolik se za daný měsíc utratilo na materiálu, mzdách, strojích a OPN.

Soupis prací - kde najdete ekonomický souhrn podle kalkulačního vzorce po položkách.

Detailně spotřeby - kde se lze podívat kolik a jaké potřeby se spotřebovali.

Dělnická výčetka - kde si můžete podívat kdo, kolik a jaký den odpracoval hodin.

Nyní najdeme nové funkce:

Stavební deník - kde najdeme automaticky generované zápisy podle vyplněných dat.

Plánování - kde najdeme mnoho filtrů pro plánování a lepší vedení stavby.

Sklad - kde najdeme databázi skladovaných materiálů a mechanizací na stavbě.

Správa účtů - kde můžeme vytvářet nové účty a přiřazovat jim práva.

Ekonomický deník není program na kalkulace, či účetnictví. Nejedná se o program, který má ambice pro samostatné vedení výstavby. Jedná se o jednoduchý software, který pomáhá účastníkům výstavby $v$ lepší pochopení a pohled na situaci na stavbě v reálném čase. Pomocí krátkých pětiminutových záznamů má stavba přehled o reálné ekonomice na stavbě a ušetří si spoustu času vyplňováním různých Excelových tabulek pro mzdy zaměstnanců, betonáže, či mechanizace. Ušetří si vedení psaných záznamů potřeb ve skladu a stavebního deníku. Všechny záznamy jsou sdílené a online $\mathrm{k}$ prohlédnutí kdykoliv a kdekoliv.

Myslím, že takový program na trhu chyběl. 


\section{Zdroje}

[1] TOMÁNKOVÁ, Jaroslava, Dana ČÁPOVÁ a Dana MĚŠŤANOVÁ. Příprava a řízení staveb. V Praze: České vysoké učení technické, 2008

[2] JELEN, Václav. Ekonomika a řízení staveb. Praha: Vydavatelství Českého vysokého učení technického, 1976

[3] ROUŠAR, Ivo. Projektové řízení technologických staveb. Praha: Grada, 2008

[4] NGUYEN, Cong Thanh. Operativní plánování v systému řízení stavebního podniku. Brno: b. t., 1975

[5] BERAN, V. and DLASK, P. Nonlinear Optimisation and Rational Cash Flow. Engineering, Construction and Architectural Management. 2007, 14(3), pp. 277-292. ISSN 0969-9988.

https://doi.org/10.1108/09699980710744917 